RESENHAS/REVIEWS 


\section{Aamir R. Mufti. Forget English! Orientalisms and World Literatures. Cambridge, MA. Harvard University Press, 2016, 304 pp.}

Adile Aslan Almond*

University of Massachusetts Amherst, Amherst

Aamir Mufti's Forget English! Orientalisms and World Literatures is a recent contribution to the field of world literature studies, yet it differs from most of its preceding examples in that some of the more celebratory statements on the recently revived concept of world literature lend themselves to a highly critical and deconstructive analysis in Mufti's book. He starts, in the Preface, by describing the irresistible force of the "promise of a unified perspective on world culture" contained in the idea of world literature, even on its most resistant or reluctant audience, yet quickly turns his attention to "a lingering sense of unease" accompanying the concept, with its "too easily achieved" resolutions, reconciliatory singularity and "easy commodification in the marketplace" (x-xi). Indeed, Mufti likens the present discussions of world literature to "an

\footnotetext{
* Adile Aslan Almond is a doctoral student and teaching associate in Comparative Literature at University of Massachusetts Amherst. She has a BA degree in Western Languages and Literatures (Bogazici University), an MA degree in Comparative Literature (Istanbul Bilgi University) and a second MA degree in Cultural Studies at Sabanci University, Istanbul. Her research interests are comparative modernisms, postcolonialism, world literature and Global South. She has worked as a teaching assistant, instructor, and translator at various institutions and universities in Turkey, Spain, Qatar and the US.
} 
intellectual correlate of the happy talk" which attended the idea of globalization only a few decades ago (xi). He argues that despite the claims otherwise, the "world" in the term "world literature" is thoroughly permeated by European concepts, classifications and languages. For him, at the core of world literature lie "the origins of bourgeois modernity" and "the culture of capitalist society," as well as the practices of colonial enterprises, which participants in contemporary discourse dismiss or overlook, while uneven power structures are barely covered by the "claims to inclusiveness" (xixii, 5). Moreover, in contrast with world literature's appeal to a borderless world and uncomplicated mobility, Mufti maintains that an enforced border regime and immobility has been the main function of one-world talk (9). His aim in Forget English is an examination of world literature in its three varieties: first as a "concept" whose genealogical roots stem from the cultural praxis of Enlightenment period, second as "a contemporary field of study" in academia, and third as a set of practices and institutional frameworks (10). Emphasizing the correlation between the rise of English and that of world literature, Mufti aims at an exploration of the relations between English and its Others, particularly the South Asian languages (11). Not surprisingly, he holds that what we call world literature is in fact the dominance of globalized English, which has assumed "the ancient Babel dream of universal comprehensibility and communication" $(13,15)$. Dubbing the current status of English as "global literary vernacular", Mufti is not so much concerned with it as a tool of literary expressivity, but more as "an assemblage and apparatus for the assimilation and domestication of diverse practices of writing (and life-worlds)" (17). Whilst forgetting English is not viable in the current state of world politics, Mufti argues for the possibility and significance of asking questions and thinking "past, around, and about it" in order to investigate its dominant status and imperial legacy (19). One of the main premises of Forget English is that world literature results from colonial structures and Orientalism, which Mufti defines as an "imperial system of cultural mapping" functioning 
under neoliberal global capitalism (20). Accordingly, in Chapter 1, where he presents "the conceptual and historical framework for the study", Mufti claims that Orientalism first formulated the idea of a world as a congregation of different communities with distinctive traditions and literary writing praxes and, hence, had a decisive part in the rise of modern bourgeois mentality (35). Chapter 2 focuses on "the institution of Indian literature" and "Calcutta Orientalism," and traces the Orientalist origins of the practices and ideas of world literature to the late eighteenth century colonial Calcutta. One of Mufti's main arguments is that theories of cultural difference, unique civilizations, and nationalisms are substantiated in Orientalist praxes, which result in orientalizing forms of thought and writing in the colony itself (37). Chapter 3 is an examination of the relationship between the globalized English and the Global South languages, which, according to Mufti, is a replica of the colonial logic of the mid-nineteenth century, as well as a survey of Anglophone novel in the subcontinent (39). The $4^{\text {th }}$ and last chapter of the book is an engagement with Auerbach's works through the mediation of Said's Orientalism (40).

Mufti opens his Preface with a hypothetical situation in which two people of different geographical origins meet, and by dissecting the possible assumptions underlying this speculative encounter illustrate the centrality of European languages, concepts and categories in the space of literature. He closes the short section by disclosing some of the politically charged aspects of the concept of world literature that its influential theorists omit, namely the problems of modern capitalist bourgeois society (xi-xii).

"Prologue: The Universal Library of World Literature" begins with a short survey of the metaphor of universal library for literature as a planet-embodying entity in the writings of such writers as Johann Wolfgang von Goethe, Thomas Babington Macaulay, Rabindranath Tagore, Jorge Luis Borges, Tayeb Salih, and Orhan Pamuk (Mufti takes up these writers in more detailed fashion at different points 
later in the book) and points out at an inherent tension between the cosmopolitan and the local in their elaborations (3). One of the concepts Mufti tackles in this section is "borderless world," the assumption of a modern world where movements across the globe are equally smooth and unhindered by any kind of boundaries. He argues that whilst capital has an enhanced mobility around the world, international borders sustained through the intersections of "class, race, ethnicity, religion, gender, or nationality" are still strictly restricted for large sections of the world's population (8). Similarly, Mufti contends, world literature works as a regulatory "border regime" system, despite its claim to the contrary (9). As he discusses it at more length at various points in the book, Mufti holds that any variations of "borderless world" talks are connected to the ascent of "the modern multinational corporation in postwar era," especially exacerbated "in the "neoliberal' post-Cold War era" $(5,92,243)$. In a parallel vein, Mufti challenges the reception of the rise of global English "as a transparently universal good," and instead calls for an inquiry into the socio-historical circumstances behind this phenomenon (13). Indeed, the book itself advocates for a critical investigation into the "naturalize[d]" and "normalize[d]" assessments about not only English but also world literature (16). While sharing the reservations of Emily Apter, Gayatri Spivak, Jonathan Arac about world literature, Mufti departs from them by claiming that the dominance of English in literary affairs is not merely limited to the current globalized/decolonized age, but in fact dates back to the late eighteenth century, where Mufti sees the origins of world literature, colonialism and Orientalism (1719). He sums up his main argument by saying that "a genealogy of world literature leads to Orientalism" (italics in the original, 19). As Mufti believes that Said's seminal work on Orientalism (since 1978) is curiously missing from the discussions of world literature while it still remains one of its tenets, albeit in altered reconfigurations, he deems it necessary to revisit some of Said's arguments, with a few corrections and extensions, in order to demonstrate their unrecognized relevance and significance for 
the contemporary debates on world-encompassing literature (2030). He sets out to show the intrinsic inequalities and asymmetries in the exchange called world literature, which is predicated on Orientalism and the Anglophone from its beginning. Although his thesis is based on a specific region, namely the subcontinent, he is of the opinion that his pattern is representative of the workings of Orientalist structures and literary relations in the modern world on a larger scale. Hence the plurals in the subtitle, Orientalisms and World Literatures (31). Touching on the debates between centerperiphery model and empire-colony model in recent discussions, Mufti encourages and himself employs a productive use of both through the tensions between the two (32-33). While offering a critique of Moretti and Casanova's sociological approach to world literature, not for using the center-periphery model, but for how they use it without proper historical contextualization, Mufti also notes the lack of recognition of the "normative force" and "teleological conception of humanity" in both of their elaborations of the concept of world literature (33). In the remainder of the section, the author, conveniently for his readers, provides the main arguments of the following four chapters (35-41). Offering an account of different destinies of British Library and the Mughal Library in the form of a "parable" and defining Hamra Abbas' artwork All Rights Reserved (2006), which is the cover image of the book, as a metaphor for "cultural possession, (mis)appropriation, reclamation, and translation," Mufti positions his book as a critical investigation into greater courses of appropriation and assimilation in the field of world literary affairs and their conspicuous outcomes, which betray colonial residues of "inequalities" (51). However, this is not to say that Mufti is a champion of "vernacular" or particular. In fact, Mufti's critical intervention into world literature studies works in a double-sided way: whilst he advocates for a historically and politically informed approach to the origins of the concept of world literature and asks for a recognition of colonial and Orientalist processes in its structures, he urges for an equally skeptical attitude toward the claims to authenticity and autonomy from the (post) 
colonial world (52-53). Mufti ends the section by explaining that the imperative form in the title is a call to a conscious awareness to the hegemonic powers of English, as the global language of literary criticism (as well as global capitalism), where the stakes of "diverse and heterogeneous practices of writing in numerous languages as (world) literature" lie (52).

Chapter 1 entitled "Where in the World is World Literature?" comprises two sections. The first called "Historicism and Orientalism: Reading the World" starts with a critical treatment of Pascal Casanova's World Republic of Letters (1999). The most fundamental disagreement Mufti has against Casanova's elaborations is the latter's claim that literary cultures from nonWestern traditions emerged and made an impact on world literature in the mid-twentieth century, which, according to the former, is a major misreading, and, dates back to the eighteenth century, "the dawn of the modern Era," when Orientalist practices of Western scholars "discovered," appraised, classified, standardized and assimilated the cultural and literal traditions of non-Western civilizations into Western circulations of thought, a process Mufti dubs as "the philological and knowledge revolution" (58). Since Casanova, Mufti continues, overlooks the Orientalist origins of world literature, she misreads Herder as well, as the latter "ought to be" regarded as a part of German and European Orientalism (59). Through a detailed discussion of the writings of Johann Gottfried Herder, William Jones, Wilhelm Schlegel, and Goethe, Mufti shows the deep entanglements between philosophical historicism and the Orientalist practices from the 1770s onwards, the latter establishing the ground for the postulations of the former (59-79). World literature, then, in its origins, is a byproduct of the legacy of philosophical historicism and Orientalism in the era of colonialism (80). The second section of the chapter entitled " $\mathrm{A}$ Heap of Ruins: colonialism, Capitalism, World Literature" is an attempt to reinstate Marx and Engel into the discussions of world 
literature. ${ }^{1}$ Mufti believes that Marx and Engels's reference to world literature in their Communist Manifesto is not meticulously analyzed, despite its frequent appearance in present-day debates, and carries out an overview of some of Marx's writings, especially those on colonialism (81-90). Marx and Engels, Mufti argues, equate the desire for world literature to the drive for a world market in a bourgeois Western world, a request simultaneously containing emancipation and destruction, deliverance in the form of superseding "national one-sidedness and narrow-mindedness" and obliteration in the shape of leveling out native societies (87). The ambivalent anticipation of Marx and Engels seems to have been fulfilled in the globalized Anglophone present age, where translation takes the front and center. At his point, Mufti introduces the debates on translation into his discussion. He states that the "naturalized" and "neutralized" reception of translation in Anglophone world literary studies, which should be merely one among many other possibilities, occludes the alternative modes of circulation, reading and writing praxes in the past or today (92). Of the two sides of the contemporary debates on the role of translation, "efficacy" versus "untranslatability" Mufti is closer to Emily Apter's position presented in her Against World Literature: On the Politics of Untranslatability (2013), which calls against the expansionist reconciliations, commodifying courses of celebratory differences and identities (92). Mufti explains that for him translation is "a social process" rather than "a problem in rhetoric or semiotics" and his interests lie in "its historical particularities as an Orientalist practice" (93).

In Chapter 2, "Orientalism and the Institution of Indian literature", Mufti shows how the colonial parameters involved in the shaping of both Indian literature per se and the subsequent Hindi/Urdu divide within the subcontinent, acquire an illuminating tone when

${ }^{1}$ For a similar attempt, see Timothy Brennan, The Empire's New Clothes, Critical Inquiry, Vol. 29, No. 2 (Winter 2003), pp. 337-367. 
considered in the context of how world literature has come to be. The first half of this argument is familiar to most South Asianists how a certain, crucial understanding of nation and essence underlay the various European attempts, both British and non-British, to construct a literary idea of an Indian tradition, with Sanskrit autochthonously inserted as its primal source. Whether, as Mufti claims, something as grand as "the birth of modern (European) comparative philology" can be traced to Schlegel and Jones remains debatable (106). It is a claim which overlooks some of the earlier philology, not least of all figures such as Jakob Reiske and the Byzantinist debates in Leipzig in the 1730s about whether Arabic or Hebrew was the older language. Almost a hundred years earlier than Jones, Leibniz was trying to find a version of the pater noster in every language. ${ }^{2}$ Nevertheless, Mufti convincingly sketches out a scenario where colonial and Orientalist vocabularies implemented a literary historicization which, not just through foreign scholars such as Jones and Schlegel, but also through the internalization of ideology in the figures of (say) Derozio and Bankimchandra, the contours of present-day, familiar entities such as India and Indian literature were able to be formed. Mufti also argues, again adopting a position which will be familiar to many in the discipline, that the separation of Hindi and Urdu was only able to be expressed as a consequence of these colonial maneuvers. Today's critical task, Mufti writes, lies in the "untangling and rearranging of the various elements congealed into seemingly distinct and autonomous [...] literary histories" (128). The novelty of the chapter lies in the way Mufti places this reading of the colonial establishment of Urdu in a larger picture of the establishment of World Literature - how the retroactive literary historicization of Urdu can be seen as a phase in the overall establishment of Indian literature on terms that are, ultimately, colonial in nature.

${ }^{2}$ For further see Ian Almond, History of Islam in German Thought, Routledge, 2010, pp. 23-28, 55. 
In Chapter 3, "Global English and Its Others", Mufti reiterates his point that the parallel between the rise of national languages and the expansion of English as a global language is a contradiction only in appearance, as English has been the tool of assimilation, first in the colonial endeavors of the past two centuries, which classified many distinct cultures into "narrowly conceived ethnonational spheres", and now as the instrument of global exchange (146). A critical analysis of this entanglement between nationalization of languages and the globalization of English is disregarded in most of the contemporary world literature studies, since many of its elaborators repeat the fallacy of "ascription of authenticity to 'local', instead of examining and denaturalizing the historical processes of vernacularization and indigenization, which will reveal their colonial genealogy" (149). According to Mufti, changes in readership, circulation and translation today are the outcomes of greater transformations in literary and cultural spheres, which, in return, point at Anglicization and Orientalization (147). He examines a scene in Tayeb Salih's novel Season of Migration to the North (1966) in order to exemplify the relations of global English and its Others $(149-152,154)$. Mufti's analysis of the English study room scene is that "the non-Western text is available [...] in English [...] that is in translation [...] as [an] 'Oriental' text-object within [...] Western 'universal' library", a state of affairs which is true for postcolonial writing in general (152). In the section entitled " 'Out of the Garrets of Bloomsburry': The Anglophone Novel from Anand to Aslam", Mufti offers a short survey of Indo-English novel and materializes his arguments in the case study of Salman Rushdie's Midnight's Children (1980). The Anglophone novel, Mufti argues, is a "translation" of non-Anglophone particulars into the global circuits of English. In this conversion, vernacular speech forms are exchanged for " “ethnicized' assimilation” dubbed as "linguistic diversity" (171). In the section called "The Ghazal among the Nations", Mufti uses the genre of the ghazal to reflect on the use of world and landscape in poetry. His close reading of phrases like "ajnab", injecting a colonial dimension into the 
poetry of Shahid, is used to pivot Mufti's own reflections on the necessarily interstitial nature of any relationship to the past. In particular, he brings Shahid's own reflections on the history of Kashmir into his argument concerning the construction of space. In this sense, Kashmir represents the complexity of modernity in that it is both a state and a victim of the modern state. After, in a slightly non-sequential moment, citing Arundhati Roy listening to a Faiz poem in the middle of a tribal/adhivasi forest as a complex moment unable to be inserted into the main discourse of World Literature, Mufti considers the English language ghazals that Shahid has written to argue that the true ghazals are the lyrics he has produced, not the "ghazals". Shahid employs a range of Urdu / Sufi / eighteenth century Northern Indian attitudes towards God and re-evokes and re-explores them in twentieth-century lyrics. Mufti reminds us that the colonial world often thought of the classical Urdu ghazal as obsolete - and the irony that the ghazal has outlived the colonial suggests that an exilic reading is necessary to bring out this buried truth in the ghazal. In a way, then, the structure of the ghazal itself can teach us something about how these dialectics are enacted in literature. But more importantly, the reintroduction of the Urdu ghazal into English by Shahid complements a tradition begun two hundred years earlier by orientalists like Jones, and (crucial for Mufti) offers the possibility of an exilic set of readers who will try to revisit various tensions and conflicts within ideas of nation and state without necessarily resurrecting their violence. Therefore, Mufti sees in Shahid's return to the ghazal a kind of hope. Mufti ends the chapter by stressing the historicity of borders - and its centrality to colonial/orientalist thought. He deliberately uses the loaded word "partition" here to reference this. In many ways, Mufti argues for a way of reading which would extract "submerged ways of thinking" from the experience of partition. Shahid offers in this respect Mufti's ideal example.

Chapter 4, “'Our Philological Home is the Earth': World Literature from Auerbach to Said" is a close reading of Erich Auerbach's 
"Philology and Weltliteratur" (1952), with some recourse to Mimesis: The Representation of Reality in Western Literature (1946). Mufti keeps the original German term Weltliteratur throughout the chapter, as is the case with the Said translation of the essay, so as to differentiate it from the "world literature" of North Atlantic-based elaborations of recent times (276). For Auerbach, we are told, the possibility of the human and the fate of cultures in the aftermath of mass self-destruction at the WW II is at the core of "Philology and Weltiteratur", a concern it shares with Claude Lévi-Strauss's Tristes Tropiques (1955) (208-10). In Lévi-Strauss's case, the urge for knowledge on exotic cultures has resulted in "monoculture" (209). In Auerbach's articulation, nationalisms have given rise to standardization and rigid uniformity under the rubric of indigenization (211-2). Hypernationalism, Auerbach seems to suggest, is a path to "Internationale of Triviality and Esperanto culture" through the annihilation of "historic national character" (214). For Mufti, Auerbach sees a dialectical process in Weltliteratur, in which the desire to analyze historical forces of culture (European humanities) is already placed within that historical logic of assimilation, and, therefore, if ever fulfilled, it would be simultaneously obliterated, while his involvement in the Europeanization of Turkish culture during his exile years in Turkey would be an ironic reflection of the greater historical sphere (2156). Mufti argues that what Auerbach overlooks in his elaboration of emergence of philosophical historicism and Weltliteratur (in which he rejects Herderian primitivist, organicist "Nordic" aesthetic historicism in favor of Giambattista Vico's "Latinate" historicism) is nothing less than the role and rise of capitalism, Orientalism, European expansionism, imperialism, and colonialism (220, 2169). In the second section of the chapter, "A World of Philology", Mufti shows how, in Auerbach's formulations, philology converges with humanism and humanities, which, disentangled from all kinds of "nation-form", position themselves via "exilic imagination and exilic persona" through an interaction between the universal and the particular (223-5). What Auerbach seems to advocate for, 
Mufti maintains, is a critical humanist-philologist who disavows all kinds of parochial nationalisms, "brooding solipsism", detached cosmopolitanisms, and, instead, embraces an outlook provided through an uprooted, displaced perspective, in which every place becomes a place of exile without a tendency for any particular place, for the aim is to understand the whole based on the particulars $(225,236)$.

According to Mufti, Auerbach's expansive discussion of the Biblical (Hebraic) and the Homeric (Hellenic or Philhellenic) as the two main modes of narrative at the core of European civilization is a kind of parabolic warning against the looming German Nationalist Socialism of his time, the former embodying history as a force of counterbalance against the latter representing legend taken to the extremes in German nationalism (228-234). Finally, in "Epilogue: 'For a Ruthless Criticism of Everything'", Mufti offers an analysis of Hardt and Negri's now classic Empire (2000) in order to suggest that some criticisms of imperialism and neoliberal capitalism fall prey to reproducing the logic of Orientalism (244-248). Mufti explains his raison d'etre in Forget English as a critically and historically informed approach to the often-ignored interactions among world literature, the Anglophone, and Orientalism (251).

Forget English fills in a significant gap in the theorization of world literature in that it demonstrates not only the global forces of power and pressure at the heart of the conceptualization of world literature but also the stakes of linguistic heterogeneity in the face of "standardization and homogenization both within and across languages and cultures that come masked as diversity" (250). It can also serve as an important textbook for graduate seminars on the theory of translation as a tool and paradigm for cross-cultural spaces. Any book which so openly employs a Saidian register in its undertaking will inevitably have its critics. Mufti can be defined as a devout Saidian scholar, a position which leaves no space for other types of interpretations regarding the origins of 
European comparative philology or for thinkers before Auerbach in the discussions of Homeric versus Hebraic in the long history of Europe. Technically, there are some repetitions in the chapters, leaving one with the feeling that the book could be shorter than it is. Nonetheless, Mufti's discussion opens up curricular questions about teaching world literature and postcolonial literature, given that the distance between the Anglophone and the vernacular might be shorter than one might imagine at first. The set of questions (11, $18,30,175)$ posed by Mufti draws attention to the structures of power dynamics that inherently rule the nature of world literature discussions, most of which run on the putative equality across the globe. Mufti highlights these asymmetries and inequalities and calls for an epistemologically less violent form and praxis of cultural interaction and transaction. Forget English is likely to stimulate a productive and critical discussion among the scholars of world literature, Global South, postcolonial studies, and literary and cultural criticism.

Recebido em: 10/06/2016

Aceito em: 23/09/2016

Publicado em janeiro de 2017 